\title{
SOIL WATER STORAGE IN AN UPLAND FOREST AFTER SELECTIVE LOGGING IN CENTRAL AMAZONIA ${ }^{(1)}$
}

\author{
S. J . F. FERREIRA(2), F. J . LUIZÃO(3), S. M. ROSS(4), \\ Y. BIOT(5) \& W. M. P. MELLO-IVO(6)
}

\begin{abstract}
SUMMARY
Soil water storage of Central Amazonian soil profiles in upland forest plots subjected to selective logging (in average, 8 trees or $34,3 \mathrm{~m}^{3}$ of timber per hectare were removed) was measured in four layers, down to a depth of $70 \mathrm{~cm}$. The study lasted 27-months and was divided in two phases: measurements were carried out nearly every week during the first 15 months; in the following year, five intensive periods of measurements were performed. Five damage levels were compared: (a) control (undisturbed forest plot); (b) centre of the clearing/ gap; (c) edge of the gap; (d) edge of the remaining forest; and (e) remaining forest. The lowest values for water storage were found in the control $(296 \pm 19.1 \mathrm{~mm})$, while the highest were observed $(333 \pm 25.8 \mathrm{~mm})$ in the centre of the gap, during the dry period. In the older gaps (7.5-8.5 year old), soil water storage was si milar to the remaining and the control forest, indicating a recovery of hydric soil properties to nearly the levels prior to selective logging.
\end{abstract}

Index terms: selective logging, soil water storage, upland rain forest, Central Amazonia.

(1) Part of the Ph. D. Thesis of the first author presented at the University of São Paulo - USP. Recebido para publicação em janeiro de 2003 e aprovado em outubro de 2003.

(2) Pesquisador da Coordenação de Pesquisas em Geociências/CPGC, INPA, Caixa Postal 478, CEP 69011-970 Manaus (AM). Email: savio@inpa.gov.br

(3) Pesquisador da Coordenação de Pesquisas em Ecologia/CPEC, INPA. E-mail: fluizao@inpa.gov.br

(4) U. K. Environmental Research \& Consultancy (ERC), University of Liverpool, England. E-mail: smross@iv.ac.uk

(5) Department for International Development (DFID), J I J end. Gatot Subroto, J akarta 10270 - I ndonésia. E-mail: yvanbiot@difid.or.id

(6) Pesquisadora da EMBRAPA Tabuleiros Costeiros. Av. Beira Mar 3250, CEP 49025-040 Aracaju (SE). E-mail: walane@cpatc.embrapa.br 


\title{
RESUMO: ARMAZENAMENTO DE ÁGUA NO SOLO APÓS EXTRAÇÃO SELETIVA DE MADEIRA EM FLORESTA DE TERRA FIRME NA AMAZÔNIA CENTRAL
}

\begin{abstract}
Foi medido o armazenamento de água em perfis de solo de $0-70 \mathrm{~cm}$, divididos em quatro camadas em parcel as defloresta deterra firmena Amazônia Central, submeti das à extração sel etiva demadeira, tendo sido retiradas, em média, 8 árvores por hectareou $34 \mathrm{~m}^{3}$ demadeira. $O$ estudo foi realizado num período de 27 meses em duas fases: na primeira, as medidas foram, na sua maioria, semanais, num período de 15 meses. Na segunda, as medidas foram fei tas em cinco períod os intensivos. F oram comparados cinco tratamentos: (a) controle (floresta intacta), (b) centro da clareira, (c) borda da clareira, (d) borda da fl oresta remanescentee (e) floresta remanescente Os val ores mais bai xos dearmazenamento de água no solo $(296 \pm 19,1 \mathrm{~mm})$ foram encontrados no controle, enquanto os mais altos foram medi dos no centro da clareira $(333 \pm 25,8 \mathrm{~mm})$, no período seco. Nas clareiras mais antigas (7,5-8,5 anos deidade), os armazenamentos deágua no sol o foram similares aos da floresta remanescente e controle, indicando a recuperação das propriedades hídricas do solo após a extração sel etiva de madeira.
\end{abstract}

Termos deindexação: armazenamento deágua no sol o, Amazônia Central, fl oresta deterra firme, extração sel etiva de árvores.

\section{NTRODUCTION}

In the Amazon uplands (about $90 \%$ of the total area), the farming potential is low due to the low natural fertility of most soils and the lack of appropriate land management in the region. On the other hand, the logging potential is high, but, again, the lack of information about adequate forest management practices limits the expansion of this activity in the Amazonian uplands. Among other factors, the sustainability of the for est management depends on the regeneration rate of the for est after logging, which is influenced by the availability of nutrients. In turn, this is highly influenced by the hydrologic cycle, which regulates both the nutrient as well as the water transfer processes in the soilplant-atmosphere system.

Soil is an open and porous system, which allows the flow of matter and energy. Even a soil covered with dense vegetation has a high water input by the effective precipitation, which is the amount of rain which reaches the soil after percolating the foliage. In the area of the present study, effective precipitation ranged from 74.2 to $87.1 \%$ (Ferreira, 1999). The output occurs by evaporation, by which water is depleted by roots, run-off and drainage. In the Yellow Latosols, which predominate in the upland forests of central Amazonia, theion exchange capacity in the upper horizons is significantly dominated by the soil organic matter, which can be responsible for up to $82 \%$ of the total cation exchange capacity of the soil (Vieira \& Santos, 1987). These soils are characterised by their easy flow of water within the profile. Despite their high clay content, often with values above $80 \%$, Y ell ow L atosols under forest show a high hydraulic conductivity of the saturated soil (Ko). One of the characteristics of these soils is the microaggregation of particles, which makes them behave like sandy soils, mainly regarding their high conductivity. Over $50 \%$ of the aggregates are in classes above $2 \mathrm{~mm}$ (Mello, 1994). Soil bulk density values in the region near Manaus are lower in the upper layers (bel ow $1 \mathrm{~kg} \mathrm{dm}^{-3}$ ), and increase with depth (Nortcliff \& Dias, 1988; Ferreira et al., 2002). In an area close to the studied one, bulk density values for a Yellow Latosol were: $0.9 \mathrm{~kg} \mathrm{dm}^{-3}$ in the A1 horizon $(0-8 \mathrm{~cm}), 1.1 \mathrm{~kg} \mathrm{dm}^{-3}$ in $A 3(8-33 \mathrm{~cm})$, and $1.2 \mathrm{~kg} \mathrm{dm}^{-3}$ in $B 2(33-70 \mathrm{~cm})$ (Corrêa, 1984).

The water retention curves obtained by Tomasella \& Hodnett (1996) and Corrêa (1984) in the region of Manaus indicated that upper soil layers show a different behaviour in relation to the deeper layers and tend to supply more water when submitted to a matric potential around $-100 \mathrm{kPa}$. Deeper soil layers do not show the same pattern, but a lower water availability for plants. Possibly, the amount of organic matter, the lower bulk density and the lower amount of clay in the upper layers are responsible for this behaviour. Corrêa (1984) al so observed that thesecurves tend to be horizontal in Yellow Latosol with a matric potential below $200 \mathrm{kPa}$. Ferreira et al. (2002) observed the same behaviour, and pointed out the low availability of water for the plants (around 11 to $18 \%$, in therange of -10 and $-1,500 \mathrm{kPa}$ of matric potentials) and a high water retention below the matric potential $1,500 \mathrm{kPa}$.

In the Amazon region, about $50 \%$ of the water that evaporates to the atmosphere returns as rain (Salati et al., 1979). Thus, deforestation can lower the water transfer to the atmosphere, which might 
cause the decrease of rains. In the study area, the water budget of nearby forests (Leopol do et al., 1993) assessed in Iysimeters filled with Yellow Latosol showed that $41.8 \%$ of the rain water was lost due to evaporation of the total rainfall, and around $26.4 \%$ from lysimeters filled with quartzose sand; the evapotranspiration from the forest canopy was estimated at $67.9 \%$, with an average daily rate of $4.05 \mathrm{~mm}$ day $^{-1}$. More recent studies estimated an average evapotranspiration potential in a range of 4.0-4.5 mm day ${ }^{-1}$, with clear seasonal variations for thetwo regional climatic periods: wet and dry season (Fisch et al., 1998).

In forests on Yellow Latosol, the role of roots is very important for water dynamics. In the upper $40 \mathrm{~cm}$ of soil, frequent rains and biological activity permit favourable conditions for the water and nutrient absorption by the root system; however, the lack of rain for over a week depletes the available water reserve for plants (Chauvel et al., 1992). A comparative study of a $2 \mathrm{~m}$ deep profile for water storage in forest and pastureland soils showed no differences in the 0-1 m layer, neither in the dry nor the wet periods (Hodnett et al., 1995). However, differences were observed in the 1-2 mlayer: during the dry period, water loss in the forest was $43 \mathrm{~mm}$, but only $13 \mathrm{~mm}$ for the pasture. This indicates that, during the dry period, the forest takes up water from deeper soil layers. Thus, when evaluating anthropic impact effects on the forest, it is necessary to take into consideration, Ionger observation periods which cover the seasonal effects on the processes and the dynamics of water storage in the soil.

The objective of the present study was to measure changes in the storage of water in the soil, during a totally period of 27 months, in an upland forest submitted to selective logging in the Central Amazonia, comparing soils under different impact classes, and different ages of selective logging.

\section{MATERIAL AND METHODS}

The experiment was carried out at INPA's Experimental Tropical Forestry Station, about 80 $\mathrm{km}$ north of Manaus, in forest management plots located between kilometres 21 and 24 on the left side of the secondary road ZF - 2 (between coordinates $02 \circ 37^{\prime}$ and $02 \circ 38^{\prime}$ ' S/60 $909^{\prime}$ and $600^{\circ} 11^{\prime}$ W). In this area, INPA runs 4-hectare experimental plots which were subjected to selective logging in J uly 1987 (M 87) and September 1993 (M93). Each time, six to ten trees (diameter at breast height above $50 \mathrm{~cm}$ ) per hectare were removed (in average 8 trees or $34.3 \mathrm{~m}^{3}$ of timber). This represented the removal of approximately $50 \%$ of the basal area of all trees with a potential commercial value called "Listed Species" (Higuchi et al., 1991). The trees were cut with a chain saw and removed with a Caterpillar D6 bulldozer, which left a gap and tractor track sites on the plots, besides the remaining forest. The experimental layout consisted of three blocks (I, II and IV), in which six 4 ha plots were randomly allocated (plots 1 to 6). An assessment of the damage produced by the selective logging of $34 \mathrm{~m}^{3} \mathrm{ha}^{-1}$ of timber in thestudy plots revealed a dramatic change in the forest structure: $25 \%$ of the area was severely affected by the formation of gaps and tractor tracks; $50 \%$ was moderately affected; and only about $25 \%$ remained intact (Biot et al., 1997).

Thesoil in thearea of the present study is a clayey Yellow Latosol, has a high clay content (>75 \%), and is similar to the soils described by Chauvel (1982) and Corrêa (1984) in nearby areas. It was devel oped on uplands of a Tertiary sediment of the Barreiras Group (Vieira \& Santos, 1987). Table 1 shows the results of soil bulk density $(\rho)$ and volumetric water content: saturated $\left(\theta_{\mathrm{s}}\right)$, submitted to matric potentials $-10\left(\theta_{10}\right)$ and $-1,500 \mathrm{kPa}\left(\theta_{1500}\right)$; Table 2 shows the main chemical characteristics of the soil in the study area.

In order to evaluate the influence of selective logging on soil water storage, the matric potential was measured directly in the field; simultaneously, the soil water content was estimated by soil water retention curves (Ferreira et al., 2002), which made a calculation of the soil water storage possible.

Table 1. Soil bulk density ( $\rho)$ and volumetric water content: saturated $\left(\theta_{\mathrm{s}}\right)$, submitted to matric potentials -10 $\left(\theta_{10}\right)$ and $-1.500 \mathrm{kPa}\left(\theta_{1500}\right)$ in the soil layers up to $1 \mathrm{~m}$ depth. $\theta_{\mathrm{s}}$ equal to the porosity. (Source: Ferreira et al., 2002)

\begin{tabular}{|c|c|c|c|c|c|}
\hline Site & Depth & $\rho$ & $\theta$ s & $\theta 10$ & $\theta 1.500$ \\
\hline & $\mathrm{cm}$ & $\mathrm{kg} \mathrm{dm}^{-3}$ & & $\mathrm{~m}^{3} \mathrm{~cm}$ & \\
\hline Block I & $0-5$ & 0,74 & 0.71 & 0.42 & 0.32 \\
\hline Block II & $0-5$ & 0,84 & 0.72 & 0.46 & 0.35 \\
\hline Block I & 10 & 1,01 & 0.58 & 0.42 & 0.36 \\
\hline Block II & 10 & 1,06 & 0.60 & 0.46 & 0.40 \\
\hline Block IV & 10 & 0,93 & 0.63 & 0.40 & 0.34 \\
\hline Block I & 20 & 1,10 & 0.59 & 0.44 & 0.38 \\
\hline Block II & 20 & 1,02 & 0.54 & 0.42 & 0.38 \\
\hline Block IV & 20 & 0,99 & 0.59 & 0.40 & 0.36 \\
\hline Block I & 30 & 1,10 & 0.53 & 0.43 & 0.39 \\
\hline Block II & 30 & 1,07 & 0.57 & 0.40 & 0.36 \\
\hline Block I & 40 & 1,07 & 0.55 & 0.43 & 0.37 \\
\hline Block II & 40 & 1,05 & 0.56 & 0.41 & 0.37 \\
\hline Block IV & 40 & 1,06 & 0.55 & 0.41 & 0.36 \\
\hline Block I & 60 & 1,09 & 0.56 & 0.43 & 0.35 \\
\hline Block II & 60 & 1,05 & 0.58 & 0.42 & 0.33 \\
\hline Block IV & 60 & 1,16 & 0.64 & 0.46 & 0.36 \\
\hline Block I & 100 & 1,16 & 0.55 & 0.46 & 0.40 \\
\hline Block II & 100 & 1,23 & 0.55 & 0.48 & 0.39 \\
\hline Block IV & 100 & 1,21 & 0.54 & 0.48 & 0.42 \\
\hline
\end{tabular}


Table 2. Values of pH, soil organic matter (SOM), extractable-P and exchangeable- $\mathrm{K}, \mathrm{Ca}, \mathrm{Mg}$ and Al in down to $60 \mathrm{~cm}$ deep soil layers. (Source: Ferreira et al., 2001)

\begin{tabular}{|c|c|c|c|c|c|c|c|}
\hline Depth & $\mathrm{pH}(\mathrm{KCl})$ & SOM & $\mathbf{P}$ & K & $\mathrm{Ca}$ & Mg & Al \\
\hline $\mathrm{cm}$ & & $\mathrm{g} \mathrm{dm}^{-3}$ & & $-r$ & $g \mathrm{dm}^{-}$ & & \\
\hline $0-10$ & 3.9 & 4.24 & 0.87 & 0.09 & 0.02 & 0.12 & \\
\hline $10-20$ & 3.98 & 2.82 & 0.6 & 0.05 & 0.15 & 0.10 & \\
\hline $20-30$ & 4 & 2.04 & 0.43 & 0.03 & 0.13 & 0.08 & 0 , \\
\hline $30-40$ & 4.09 & 1.88 & 0.5 & 0.03 & 0.09 & 0.08 & \\
\hline $40-60$ & 4.14 & 2.23 & 0.33 & 0.03 & 0.08 & 0.09 & 0.33 \\
\hline
\end{tabular}

The field work was devel oped in two phases. The first began in December 1993 (3 months after selective logging) and lasted 15 months, until February 1995, investigating three control plots and three others, which were submitted to selective logging in 1993, with weekly measurements, in most cases. For the sel ectively logged plots, fivetreatment situations were investigated: control 93, centre of the gap (CG93), edge of gap (EG93), edge of the remaining forest (ERF93) and remaining forest (RF93). The second phase consisted of five periods with intensive field measurements throughout one year: the first one was carried out in February 1995 (wet period), 17 months after the 1993 selective logging; the second in May 1995 (late wet period); the third in J uly 1995 (dry period), the fourth in October 1995 (dry period); and the fifth in J anuary 1996 (early wet period). In the last period, only block IV was investigated, comparing three plots: control, one plot managed in 1993, and one submitted to selective logging in 1987 . The studied treatments were: control, 1993 centre of gap (CG93), 1987 centre of gap (CG87), and 1987 remaining forest (RF 87).

\section{Matric potential and soil water storage}

The soil matric potential $\left(\psi_{\mathrm{m}}\right)$ was assessed in direct measurements, at depths of 10, 20, 40, and $60 \mathrm{~cm}$ by tensiometers, which assess the "retention forces" that act on soil water. In randomly chosen locations, in the middle of the plots (between 50 and $150 \mathrm{~m}$ of each control plot), three tensiometer arrays (with four tensiometers, one at each chosen depth) were installed. In the plot submitted to selective logging in 1987, two tensiometer arrays were installed in the middle of the gap and two more in the remaining forest. The matric potential $(\mathrm{cm}$ of water column) is expressed by the equation:

$$
\psi_{\mathrm{m}}=-12,6 \mathrm{~h}_{\mathrm{Hg}}+\mathrm{h}_{\mathrm{c}}+\mathrm{h}_{\mathrm{p}}
$$

where: $h_{H g}=$ height of mercury $(\mathrm{Hg})$ from the level of the container $(\mathrm{cm})$, measured with a rule; $h_{c}=$ height of the $\mathrm{Hg}$ level to the soil $(\mathrm{cm}) ; h_{p}=$ depth of the container $(\mathrm{cm})$. The values of soil matric potential $\left(\psi_{\mathrm{m}}\right)$ expressed in $\mathrm{cm}$ of water column were transformed to $\mathrm{kPa}$.

In the plots submitted to selective logging, four tensiometer arrays were installed at the same depths as mentioned above, on four damage types caused by timber extraction: centre of gap, edge of gap, edge of remaining forest and remaining forest. In 1993, the tensiometers were installed in September and October, soon after logging. These tensiometers were equipped with a vacuum gauge (SOILMOISTURE EQUIPMENT CORP.), which indicates soil water tension in centibar.

The soil water storage $\left(A_{L}\right)$ was calculated with soil moisture estimates, obtained from water retention curves (Ferreira et al., 2002), and the results of matric potentials, for $70 \mathrm{~cm}$ deep soil layers. In thearea of the present study, theseauthors observed high values of saturated moisture which corresponded to a porous space or porosity above $50 \%$, and verified moreover that the relative retained water content bel ow the matric potential $1,500 \mathrm{kPa}$ increased, varying between 0.31 and $0.40 \mathrm{~cm}^{3} \mathrm{~cm}^{-3}$.

The following calculation was used to determine the soil water storage:

$$
\mathrm{A}_{\mathrm{L}}=\mathrm{A}_{70}=\sum_{\mathrm{i}=1}^{\mathrm{n}} \mathrm{A}_{\mathrm{i}}
$$

where $A_{1}=\theta_{1} \cdot \Delta z_{1}, A_{2}=\theta_{2} \cdot \Delta z_{2}, A_{3}=\theta_{3} \cdot \Delta z_{3}, A_{4}=\theta_{4} \cdot \Delta z_{4}$, and $\theta_{1}, \theta_{2}, \theta_{3}, \theta_{4}$ are the volumetric units and $\Delta z_{1}=$ $15 \mathrm{~cm}, \Delta z_{2}=15 \mathrm{~cm}, \Delta z_{3}=20 \mathrm{~cm}$, and $\Delta z_{4}=20 \mathrm{~cm}$ the thickness of the depth increments.

In the two phases of the current study, statistical analyses were carried out throughout the treatments, using the Variance Analysis, followed by the Tukey Test, for differences in soil water storage. In the first one, the 15-month period was split into three distinct climatic periods: J anuary to J uly/94 (wet period); J uly to November/94 (dry period); and December/94 to February/95 (dry-wet transition). In the second phase, the data obtained in the periods were grouped as follows: from February to May (wet period); from J uly to October (dry period); and from November to J anuary (drywet transition).

\section{RESULTS AND DISCUSSION}

\section{Soil water storage in logged plots}

The soil water retention curves and the AW (available water) estimates sugested by Ferreira (1999) showed that the studied soil profiles have a very low water availability for the plants even 
though they presented porosities above $50 \%$. F or soil profiles down to a depth of $70 \mathrm{~cm}$, the maximum storage (saturated) reached $406 \mathrm{~mm}$, whilst the potential of $-10 \mathrm{kPa}$, corresponding to the so-called "field capacity storage", lay between 296 and $348 \mathrm{~mm}$ (Table 3). The result was very close to the average value of $254 \mathrm{~mm}$, which corresponds to ove $60 \%$ of the storage capacity, which is when the water cannot be taken up by plants, as it is retained in potentials from -1,500 kPa (corresponding to the "permanent wilting point").

The highest value of soil water storage, $393 \mathrm{~mm}$, measured in the centre of the gap in block IV during the wet period, represented $94.8 \%$ of the saturated value. The lowest value, $264 \mathrm{~mm}$, was recorded in the control plots of the blocks II, IV and in the remaining forest of block IV during the driest period of the year, after one week with no rain. The value represented, respectively, $3 \%$ (control plot in block II) and $5.6 \%$ (control plot and remaining forest of block IV) of the water that the $70 \mathrm{~cm}$ deep profile can make available to the plants. Considering that the daily rate of evapotranspiration lies around $4 \mathrm{~mm}$ (Fisch et al., 1998), the control pl ot of block II would have water available for plants for no more than 2 days, whilst the control plot and the remaining forest of block IV would have water available for 3 days. In the control plot of block I, the recorded value for storage was greater $(273 \mathrm{~mm})$ than in the other two blocks on the same day, representing a water availability for the plants for 4 days. In the gap centres, the lowest value found for the three blocks was $280 \mathrm{~mm}$, which corresponds to $18.6 \%$ of the saturation for the $70 \mathrm{~cm}$ deep profile, providing water to the plants for over 11 days. The low water storage capacity in forest soils has been reported earlier by Chauvel et al. (1992), who estimated that the lack of rain for more than one week would deplete the available water supply to the plants in the upper $40 \mathrm{~cm}$. However, Hodnett et al. (1995) observed that the forest takes up water from deeper layers and thus resists to longer dry periods. The use of plants with a shallow root system would therefore not be viable in a forest plantation, if there is no replenishment of water by irrigation, in case of absence of rains for more than one week.

The water storage patterns were similar in both the forest control and gap centres, throughout the first 15 months of continuous measurements (Figure 1). However, the differences between storage values were higher in block II. The stored soil water was higher in the gaps produced by selective logging (between 290 and $393 \mathrm{~mm}$ ) than in the control plots (between 264 and $340 \mathrm{~mm}$ ). This indicates that the soil underneath the forest has less water available for plants than the soil under sites damaged by sel ectivelogging, theyear round, as can be seen by the range of the water storage values found in blocks I and II (59 and $67 \mathrm{~mm}$, respectively).
Table 3. Values of soil water storage (A), in $\mathrm{mm}$, for a profile down to $70 \mathrm{~cm}$, considering the saturated profile $\left(\theta_{s}\right)$ at field capacity conditions $\left(\theta_{100}\right)$ and at the permanent wilting point $\left(\theta_{15.000}\right)$, in the control plots and in selectively logged plots.

\begin{tabular}{cccc}
\hline Block & $\mathbf{A}_{\mathbf{7 0}}\left(\boldsymbol{\theta}_{\mathbf{s}}\right)$ & $\mathbf{A}_{\mathbf{7 0}}\left(\boldsymbol{\theta}_{\mathbf{1 0 0})}\right.$ & $\mathbf{A}_{\mathbf{7 0}}\left(\boldsymbol{\theta}_{\mathbf{1 5 0 0 0})}\right.$ \\
\hline I - control & 397 & 302 & 255 \\
I - logged & 399 & 306 & 236 \\
II - control & 398 & 297 & 256 \\
II - logged & 409 & 348 & 274 \\
IV - control & 422 & 296 & 250 \\
IV - logged & 411 & 328 & 251 \\
\hline
\end{tabular}

Except for the gap centre in block II with a difference of $72 \mathrm{~mm}$ between the lowest and highest value, the other classes, in all blocks, have differences, with a maximum value of $93 \mathrm{~mm}$ (centre of gap in block IV). Hodnett et al. (1996), comparing deeper soils profiles $(2 \mathrm{~m})$ in forest and pastureareas near Manaus, found that maximum seasonal variation of the storage values in the soil were $154 \mathrm{~mm}$ for the forest and $132 \mathrm{~mm}$ for the pasture. This is an indication of a greater soil water uptake occurring in the forest, due to a greater plant root biomass.

Different processes of water flow, likeinfiltration, redistribution, evaporation and plant uptake influence soil water storage. The higher values in the gaps should be related to a greater input of rainwater in these locations (with less vegetation interception) and to a reduced uptake by the plant roots, which are very important processes in the water transfer from the system soil-plantatmosphere. Accordingly, selectively logged plots (like the centre of the gaps) could be expected to present higher water storage, due to a lower plant cover and, consequently, lower plant demand for water.

The grouping of water storage data (Table 4) into three climactic periods (wet period - J anuary to J une/94; dry period - J uly to N ovember/94; and drywet transition - December/94 to February/95) has shown significant differences at $5 \%$ level among the damage classes: control, centre of the gap (CG93), edge of gap with forest (BC93), edge of remaining forest with gap (ERF93) and remaining forest (RF93). The blocks also showed significant differences of soil water within each climatic period (Table 4). Selective logging caused differences in soil water storage mainly in the gaps and at the edges of the gaps, where the storage values were higher than in the other treatments (Table 5). During the wet period and the dry-wet transition, the difference between the means of the control and the gaps was $30 \mathrm{~mm}$ of water, while in the dry period the difference was $37 \mathrm{~mm}$, indicating a trend of the soil 


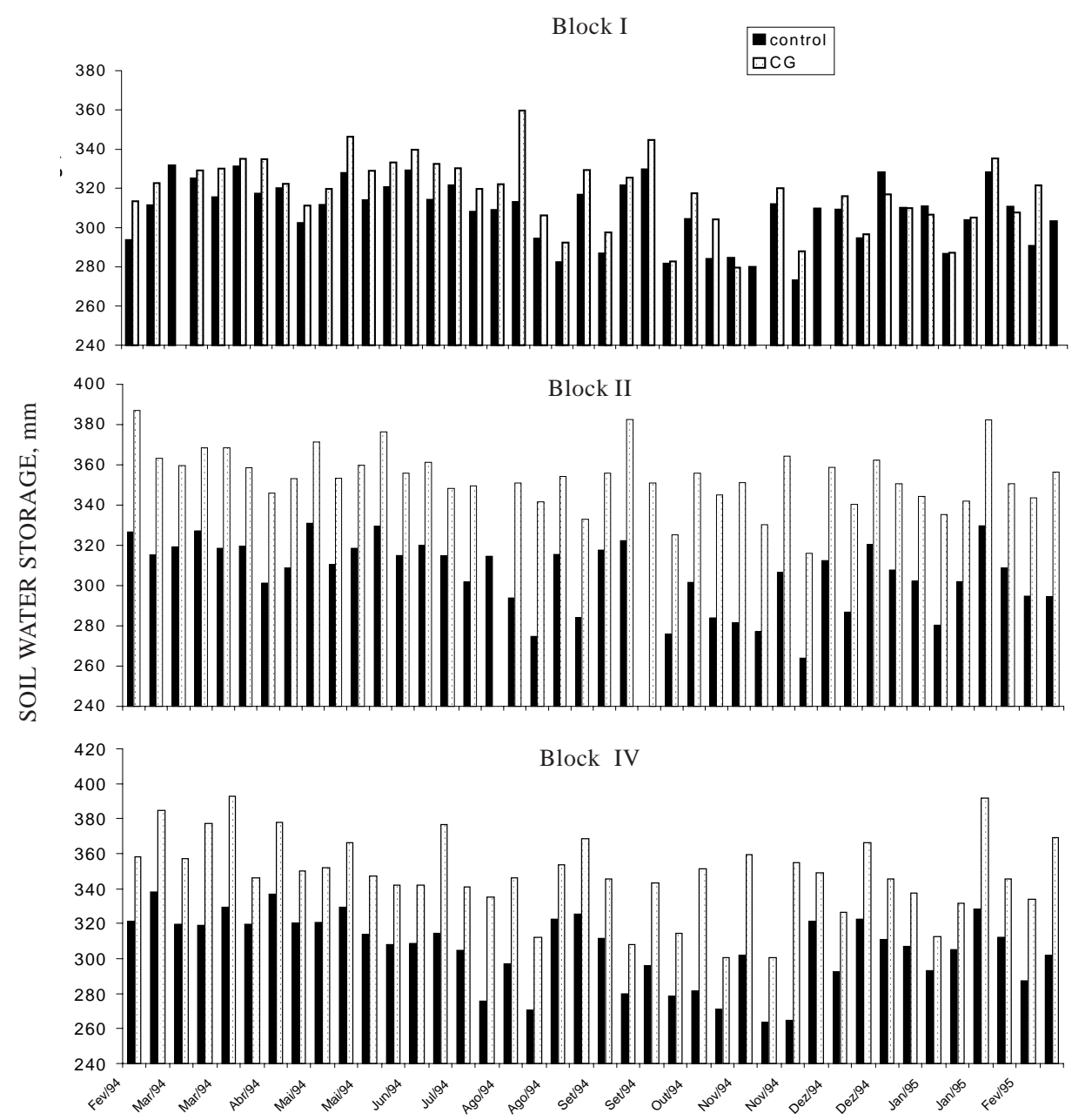

Figure 1. Soil water storage in the forest control and centre of gaps (CG), in blocks I, II, and IV.

under the for est tolose more water. The remaining forest showed no significant differences among the control plots, but its water storage was lower than in the gap centres and at the edges of the gaps, for all three climatic periods. In the measurements carried out just after the logging, that is, in the wet period, themeans of the control and remaining forest treatments differed from the edge of the remaining forest, but this fact was not observed in the two following periods. This fact was ascribed to thefaster vegetation growth on the edges of the remaining forest.

The average value of soil water storage for the three periods was $306 \mathrm{~mm}$ for the control plots and $339 \mathrm{~mm}$ for the gaps. If this difference in the data were to be extrapolated to a deforested area in Amazonia, it will be noticed that a part of this water, which reaches the soil surface, will not return to the atmosphere through the evapotranspiration process. This is one of the main concerns about climate in the Amazonia, since this decrease of water transfer from the forest to the atmosphere will also decrease the formation of clouds and rains in the region. If the Amazon forest were replaced by
Table 4. Analysis of variance for soil water storage, in three climatic periods

\begin{tabular}{|c|c|c|c|c|}
\hline Source & GL & SQ & $\mathbf{Q M}$ & $\mathbf{F}$ \\
\hline \multicolumn{5}{|c|}{ Wet period } \\
\hline $\begin{array}{l}\text { Treatment } \\
\text { Blocks } \\
\text { Residue }\end{array}$ & $\begin{array}{r}4 \\
2 \\
197\end{array}$ & $\begin{array}{r}34574.6 \\
7253.2 \\
44476.7\end{array}$ & $\begin{array}{r}8643.7 \\
3626.6 \\
225.8\end{array}$ & $\begin{array}{l}38.3^{*} \\
16.1^{*}\end{array}$ \\
\hline Total & 203 & & & \\
\hline \multicolumn{5}{|c|}{ Dry period } \\
\hline $\begin{array}{l}\text { Treatment } \\
\text { Blocks } \\
\text { Residue }\end{array}$ & $\begin{array}{r}4 \\
2 \\
197\end{array}$ & $\begin{array}{r}51061 \\
5337 \\
111344\end{array}$ & $\begin{array}{r}12765 \\
2669 \\
565\end{array}$ & $\begin{array}{r}22.6^{*} \\
4.7^{*}\end{array}$ \\
\hline Total & 203 & & & \\
\hline \multicolumn{5}{|c|}{ Dry-wet transition } \\
\hline $\begin{array}{l}\text { Treatment } \\
\text { Blocks } \\
\text { Residue }\end{array}$ & $\begin{array}{r}4 \\
2 \\
134\end{array}$ & $\begin{array}{r}25528 \\
6070 \\
57389\end{array}$ & $\begin{array}{r}6382 \\
3035 \\
428\end{array}$ & $\begin{array}{r}14.9 * \\
7.1^{*}\end{array}$ \\
\hline Total & 140 & & & \\
\hline
\end{tabular}

* Significant at 5 \% level. 
Table 5. Tukey test for water storage means, considering three climatic periods (wet, dry and dry-wet transition) among the treatments produced in 1993: control, gap centre (CG), gap edge $(B C)$, edge of remaining forest (ERF) and remaining forest (RF).

\begin{tabular}{lccc}
\hline & Rainy & Dry & Transition \\
\hline Control & $319^{a}$ & $296^{a}$ & $305^{a}$ \\
CG & $349^{c}$ & $333^{b}$ & $335^{b}$ \\
BC & $348^{c}$ & $328^{b}$ & $332^{b}$ \\
ERF & $326^{\mathrm{b}}$ & $304^{\mathrm{a}}$ & $310^{\mathrm{a}}$ \\
RF & $323^{\mathrm{ab}}$ & $300^{\mathrm{a}}$ & $306^{\mathrm{a}}$ \\
\hline
\end{tabular}

pasture, the reduction of the annual rain volume could reach $20 \%$ (Nobre \& Gash, 1997). In the present study, gap soils resulting from selective logging, down to a depth of $70 \mathrm{~cm}$, retained a water stock just above $10 \%$ of the soil under the intact forest.

\section{Comparison of ages of selective logging}

The soil water storage measured during intensive fiel d campaigns in 1995-96 (second phase) compared forest pl ots submitted to a similar timber extraction level at different times: $1.5-2.5$ years before (late 1993) and 7.5-8.5 years before (1987). The results also showed significant differences among the studied treatments (Table 6). I n the wet period, the means of soil water storage for control, remaining forest, gap centre of 1987 and gap centre of 1993 were similar to the dry-wet transition. Significantly higher soil water storage values were only found in the more recent gaps (CG93) (Table 7). No significant differences were found between 7-8 yearold gaps (CG87) and the remaining forest of 1987 (RF 87) or the control plot (Tables 6 and 7). This is an indication that soil properties, including soil water storage capacity of the older centre of the gap, returns to a similar condition to that of the control treatment and theremaining forest, after a few years of moder ate logging. The main reason for this must have been the intense growth of secondary vegetation in this older gaps, with a well devel oped canopy, which intercepts a considerable part of the rain water, together with a well-developed root system which absorbs part of the water available in the soil.

\section{CONCLUSIONS}

1. In the first year after sel ective logging, the soil water storage was higher in the more severely damaged classes (centre and edge of gaps) than in
Table 6. Analysis of variance for soil water storage, considering four treatments and three climatic periods: wet, dry and dry-wet transition

\begin{tabular}{lrcrc}
\hline \multicolumn{1}{c}{ Source } & GL & SQ & QM & F \\
\hline Treatment & 3 & 3957 & 1319 & $11.6^{*}$ \\
$\begin{array}{l}\text { Residue } \\
\text { Total }\end{array}$ & 36 & 4080 & 113 & \\
& 39 & & & \\
Treatment & 3 & 9297 & 3099 & $26.5^{*}$ \\
Residue & 64 & 7494 & 117 & \\
Total & 67 & & & \\
& & Wet period & & \\
Treatment & 3 & 8434 & 2811 & $36.9^{*}$ \\
Residue & 34 & 2590 & 76 & \\
Total & 37 & & & \\
\end{tabular}

* Significant at a $5 \%$ level.

Table 7. Tukey test for soil water storage, considering three climatic periods (wet, dry, and dry-wet transition) among the treatments: control, gap centre from 1993 (CG93) and 1987 (CG87), and remaining forest from 1987 (RF 87)

\begin{tabular}{llll}
\hline & Wet & Dry & Transition \\
\hline Control & $324 \mathrm{a}$ & $284 \mathrm{a}$ & $325 \mathrm{a}$ \\
RF87 & $326 \mathrm{a}$ & $281 \mathrm{~b}$ & $822 \mathrm{ab}$ \\
CG87 & $336 \mathrm{ab}$ & $389 \mathrm{Bb}$ & $332 \mathrm{ab}$ \\
CG93 & $348 \mathrm{~b}$ & $311 \mathrm{~b}$ & $361 \mathrm{~b}$ \\
\hline
\end{tabular}

Means with the same letter in the columns indicate no difference among treatments at a $5 \%$ probability level.

the control plots, in all three climatic periods (wet, dry and dry-wet transition). Thus, the $70 \mathrm{~cm}$ soil profile in the gap stored more water than the soil in the other treatments.

2. However, soil water storage in the 7.5-8.5 year old gaps did not show differences to the remaining forest or the control forest, indicating a recovery of hydraulic conditions of the soil.

3. In both cases, the presence or absence of a vegetation cover, with the consequent rain water interception and a higher absorption of the available soil water by roots, were responsiblefor the observed differences.

\section{ACKNOWLEDGE MENTS}

We would like to thankJ oséGeraldo Martins dos Santos, Antônia Gomes Neta Pinto, J oão Augusto 
Dantas de Oliveira, Pedrinho de Almeida Paiva, $\mathrm{J}$ onas de Oliveira Moraes, Sandoval do Nascimento Morais (INPA), Eng ${ }^{\circ}$. Max Sarrazin (IRD- French Guyana), and Folco H. H. H. van Rij for their help. The research was supported by DFID (Department for I nternational Development - United Kingdom).

\section{LITERATURE CITED}

BIOT, Y.; FERRAZ, J.; LUIZÃO, F. \& MINETE, L. Levantamento de habitats após a exploração seletiva de madeira.. Projeto BIONTE - Biomassa e nutrientes florestais - Relatóriofinal. Manaus, MCT/INPA, 1997. p.6785.

CHAUVEL, A. Os Latossolos Amarelos álicos argilosos dentro dos ecossistemas das bacias experimentais do INPA e da região vizinha. Acta Amaz., 12:47-60, 1982.

CHAUVEL, A.; VITAL, A.R.T.; LUCAS, Y.; DESJ ARDINS, T.; FRANKEN, W.; LUIZÃO, F.J .; A-ARAGUÁS, L.; ROZANSKI, K. \& BEDMAR, A.P. O papel das raízes no ciclo hidrológico da floresta Amazônica. In: CONGRESSO BRASILEIRO DE METEOROLOGIA, 7., São Paulo, 1992. Anais. São Paulo, 1992. p.29-37.

CORRÊA, J.C. Características físico-hidrícas dos sol os Iatossolo amarelo, podzólico vermel ho-amarel o e podzol hidromórfico do estado do Amazonas. Pesq. Agropec. Bras., 19:347-360, 1984.

FERREIRA, S.J.F. Ciclo hidrológico e de nutrientes em uma área de manejo florestal em floresta de terra firme na Amazônia Central. São Carlos, Escola de Engenharia de São Carlos, Universidade de São Paulo, 1999. 188p. (Tese de Doutorado)

FERREIRA, S.J .F.; CRESTANA, S.; LUIZÃO, F.J . \& MIRANDA, S.A.F. Nutrientes no solo em floresta de terra firme cortada seletivamente na Amazônia Central. Acta Amaz., 31:381396, 2001.

FERREIRA, S.J .F.; LUIZÃO, F.J .; MELLO-IVO, W.; ROSS, S.M. \& BIOT, Y. Propriedades físicas do solo após extração seletiva de madeira na Amazônia central. Acta Amaz., 32:449-466, 2002.

FISCH, G.; MARENGO, J .A. \& NOBRE, C.A. U ma revisão geral sobre o clima da Amazônia. Acta Amaz., 28:101-126, 1998.
HIGUCHI, N.; VIEIRA, G.; MINETE, L.J .; FREITAS, J.V. \& J ARDIM, F.C.S. Sistema S.E.L. (Seleção de Espécies Listadas) para manejar a floresta tropical úmida de terra firme da Amazônia. In: VAL, A.L.; FIGLIOULO, R. \& FELDBERG, E., eds. Bases científicas para estratégias de preservação e desenvolvimento da Amazônia. Manaus, Instituto Nacional de Pesquisas da Amazônia, 1991. v.1. p.197-206.

HODNETT, M.G.; SILVA, L.P.; ROCHA, H.R. \& SENNA, R.C. Seasonal soil water storage changes beneath central Amazonian rainforest and pasture. J . Hydrol., 170:233-254, 1995.

HODNETT, M.G.; OYAMA, M.D.; TOMASELLA, J.\& MARQUES FILHO, A.O. Comparisons of long-term soil water storage behaviour under pasture and forest in three areas of Amazonia. In: GASH, J.H.C. \& NOBRE, C.A.; ROBERTS, J.M. \& VICTORIA, R.L., eds. Amazonian deforestation and climate. Chichester, J ohn Willey, 1996. p.57-77.

LEOPOLDO, P.R.; CHAVES, J.G. \& FRANKEN, W.K. Solar energy budgets in central Amazonian ecosystems: a comparison between natural forest and bare soil areas. For. Ecol. Manag., 59:313-328, 1993.

MELLO, W. Efeito da derrubada seletiva de madeira na estrutura de um latossolo sob floresta de terra firme na Amazônia Central. In: REUNIÃO BRASILEIRA DE MANEJ O E CONSERVAÇÃO DO SOLO E DA ÁGUA, 10., Forianópolis, 1994. Resumos. Florianópolis, Sociedade Brasileira de Ciência do Solo, 1994. p.380.

NOBRE, C.A. \& GASH, J. Desmatamento muda clima da Amazônia. Ci. Hoje, 22:32-41, 1997.

NORTICLIFF, S. \& DIAS, A.C.D.C. The change in soil physical conditions resulting from forest clearance in the humic tropics. J . Biogeog., 15:61-66, 1988.

SALATI, E.; DALL 'OLIO, A.; MATSUI, E. \& GAT, J R. Recycling of water in the Amazon Basin: an isotopic study. Water Res. Res., 15:1250-1258, 1979.

TOMASELLA, J . \& HODNETT, M.G. Soil Hydraulic Properties and van Genuchten Parameters for an oxisol under pasture in Central Amazonia. In: GASH, J.H.C.; NOBRE, C.A.; ROBERTS, J.M. \& VICTORIA, R.L., eds. Amazonian deforestation and climate. Chichester, J ohn Willey, 1996. p.101-124.

VIEIRA, L.S. \& SANTOS, P.C.T.C. Amazônia: seus sol os e outros recursos naturais. São Paulo, Agronômica Ceres, 1987. 416p. 